\title{
SUBJECTIVE PREFERENCES OF CRITERION-ORIENTED SUPPORT OF PROFESSIONAL ACTIVITIES OF MANAGERS
}

\author{
Fairuza S. Ismagilova, \\ Galina S. Mirolyubova \\ First Russian President B.N. Yeltsyn Ural Federal University, \\ Yekaterinburg, Russia
}

This article deals with the results of a pilot research of a subjective system of activity criteria represented in professional experience of business managers from the Ural region. The authors investigate the question of changes in an individual criterionoriented system of assessing effectiveness of activities depending on a subject's professional experience and his/her position. The cluster analysis helped to single out groups of criteria that underwent a preliminary quantitative and qualitative analysis. A complex interdisciplinary approach was used in this research.

Keywords: professional experience, a criterion-oriented support of professional activities of managers; assessment of professional activities effectiveness.

While accumulating professional experience, employees develop and improve a subjective system of assessments and criteria of this process, as well as of the content and results of their professional activities. This system represents organizational and assignment instructions, rules, requirements, norms and standards that an employee should follow and that were specifically interpreted by an employee and assigned a subjective meaning. The result of such transformation is a unique content of the professional experience that "allows noticing fine details of the process, reacting to minor, almost "unapparent" changes in the world and in an object, to control (prevent and handle) movements, actions, and processes in the surrounding world" (Strelkov, 2008), and that serves as a basis for professional skills. The system of subjective criteria for assessing professional activities, the degree of differentiation and congruency of activities provide evidence of not only a qualitative content of an employee's 
work experience, but of his/her ability to work out the very criteria for appraising activities as well, which is important under hard-to-standardize professional activities. As a rule, managerial activities are described in the most general terms, and this circumstance helps to modify its boundaries depending on a situation and equips a scholar with flexibility in setting targets and using methods to obtain appropriate results.

The analysis of instructions carried out within the framework of our research in professional experience shows that promotion is accompanied by a shift from enumeration of job functions (job-related manuals or worksheets) to designation of tasks assigned to an employee (job description) and subsequently to designation of solely the objectives of activities (e.g., to derive or increase a certain amount of profit, to expand a market share) and area of responsibility (e.g., a company's behavior in the market and internal processes of a company) for executives.

The need for a subjective system of criteria for assessing activities is to a certain extent conditioned by the fact that a specialist has to interact with colleagues from related professional spheres to accomplish metafunctional tasks. This statement can be illustrated by interaction of a marketing expert with a system administrator, a key production sector manager with a repair service manager, and so forth. In the event of an interfunctional dialogue, it is crucial that criteria for assessing activities should be intelligible to a specialist him/herself, and should also be accurately formulated in the manner clear enough to other people. Therefore, the presence of tailored professional activities criteria turns out to be the most important condition for professionalism, with their significance increasing as a person gets promoted.

\section{Research problem}

One can not state that criteria emerged in professional experience are always objectively the most reliable. On the contrary, the negative tendency to identify criteria of urgency and importance and, as a consequence, to substitute the notion "it is important" by the notion "it is urgent": what becomes important is things that are really urgent at the moment, not things that are objectively important, has been discussed a lot in the domain of management. The same substitution can be traced in long-term strategic tasks that are postponed due to urgency or habitualness of current tasks. 
The results of our research in problems of professional activities carried out in 2008-2010 and involving mid-level and top-level executives of companies from the Ural region determine the relevance of the research in psychological aspects of criterion-oriented support of professional activities. In particular, it is suggested by the following facts:

- more than one third of problems are to some extent linked to the respondents' need to work out their own criteria for assessing effectiveness of professional activities;

- a total number of problems derived from insufficiency or absence of necessary criteria;

- a positive strong dynamics of increasing the number of problems caused by a criterion-oriented support of activities revealed during the research;

- explicitly or implicitly expressed respondents' need for new criteria and approaches due to a varying organizational environment and social-and-economic situation in general.

Thus, we can outline the boundaries of an actual research field in a labor psychology having a clear-cut practical focus:

1. Given that the criteria for assessing activities effectiveness are an important part of professional experience, the presence of an individual system of criteria, their number, content, and relations, as well as congruency (adequacy) of activities reflect professionalism of an employee.

2. Both managers and leading specialists of modern companies of different types and fields demand the following:

- availability of information about a range of scientifically based and practically tested criteria for assessing professional activities;

- monitoring and revising the criteria developed during an individual practice;

- criteria that allow forecasting and taking appropriate preventive measures.

We believe that a research in psychological aspects of a criterion-oriented support of professional activities is so crucial because it is directly related to solution of problems associated with effectiveness of activities: firstly, a clear and sufficiently subjective system of criteria sets a model to follow; secondly, it indirectly determines an organizational and activityrelated orientation of an employee (an action "in conformity with" or "contrary to" the existing work standards). The amount and content of 
the criteria set permit supposing what is understood under effectiveness of activities.

It is an objective of this research to define main psychological and economic constructs of indicators of professional activities of a manager throught the analysis of criteria for assessing activities, as well as to reveal similarities and differences in a criterion-oriented support of activities in managers having different managerial experience.

Working hypotheses verified in this research are as follows: 1) a tendency to substitute criteria of professional activities for criteria of economic and organizational activity efficiency is typical of managers in general; 2) criteria for increasing profitability and criteria for reducing costs predominantly do not agree with one another and exist as two separate independent groups within the system of a criterion-oriented support of managerial activities; 3 ) criteria for assessing activities related to the maintenance of a current company strategy dominate over criteria for assessing activities related to the process of organizational changes.

\section{Theoretical background}

Companies working in a competitive environment and oriented at development, achieve their main target (i.e. to get and increase profit) by two ways: either by increasing their profitability through enhancing sales volume or upward adjustment of price, or through cutting their expenses due to reduction of costs. On the one hand, it makes sense if activities of a manager responsible for achievement of organizational targets will be appraised in terms of operating efficiency, too. Such approach to appraisal is used in the Western management practice and is considered to be as a "measure (degree) of managerial ability to generate profit and operate costs". In this case, a productivity formula can be represented by the following ratio: profit before fixed charges x $100 \div$ Sales revenue.

The problem of such approach to assessment of operating efficiency of a manager in Russian companies can be explained by two reasons. Firstly, such approach is possible only provided that a company has job standards for a manager that are understood as "activities in terms of quantitative and qualitative results expected from each employee". Such standards normally allow using results-oriented appraisals of behavior (Keith \& Madhukar, 2006). In this case, it appears possible to reveal if the target is achieved by way of minimal labor efforts. As a rule, Russian companies 
do not have clear-cut work standards for managers, said circumstance hampering the use of such approach to assess effectiveness of professional activities. Secondly, there are no sufficient grounds to identify manager's labor with a proper organizational activity to the fullest extent.

A "performance efficiency" indicator, which is understood as a ratio of an actual output to a desired (planned) output expressed in per cent, is frequently employed in order to overcome this obstacle (Fletcher, 2008). This indicator helps to estimate whether a subject has achieved the objectives.

However, given relative freedom of choice contemporary executives have, it is important for a company that its executives should be oriented as much as possible to such an indicator as "capacity for work", "quality of work" that is referred to in foreign literature as a coefficient of performance (COP). The coefficient of performance (COP) is usually defined as a net result (outcome) to an amount of consumed work or energy input. In other words, the COP psychologically reflects an attitude to achievement of certain results with minimum possible costs or to manufacture of a maximum possible amount of products from a given quantity of resources, i.e. an attitude to efficiency.

The question of effectiveness of activities, or labour quality, both at the individual level and at the company level remains one of the complicated for practice and theory, regardless of its urgency in view of the modern trend to industrial modernization and innovative development of Russian companies. In particular, our research in psychological conditions for putting innovative strategies into practice in companies of the Ural region indicated that the estimate of a ratio between profits and costs had not become popular in managerial activity (Ismagilova \& Mirolyubova, 2009). The problem of criteria and methods for assessing effectiveness remains one of the most controversial in economic sciences. Psychological and economic constructs of indicators of managerial professional activities have not been studied in labor psychology yet.

Samples. 58 executives of industrial companies of the Ural region aged from 27 to 40 participated in the research. All participants are students of the Presidential Program for Training Managers and Executives for Enterprises of National Economy (Business School of the Ural Federal University, Yekaterinburg). Representativeness of sample is confirmed by the fact that all the participants have more than 3-year experience in management. 


\section{Selection and Description of the Method}

Specific character and novelty of the topic requires a research technique that supposes activation and a targeted inclusion of the participants into the process. In order to reveal subjective preferences of a criterion-oriented support of professional activities of managers, we used a simulated event technique. In particular, the procedure included a task in which the participants were to appraise efficiency of their own activities according to key (in their opinion) criteria and to distribute remuneration for work depending on significance of these criteria. A list of criteria, their distribution into groups characterizing a constant (maintaining a standard of activities established in a company) and a variable (changing a standard of activities established in a company) part of the remuneration were recorded. Content analysis was used to process the obtained material. The criteria suggested by the participants were identified in accordance with the given classification with qualitative units of the content analysis in terms of corresponding empirical attributes.

\section{Procedures and instruments}

At the first stage, we introduced an auxiliary (artificial) classification of organizational strategic targets of a company and singled out two main groups of targeted orientation of an organizational activities: orientation to changes (development) and orientation to maintenance of the existing order (i.e. functioning in predetermined conditions in conformity with set standards and regulations). Moreover, we singled out five main groups on the basis of a simulated clustering of realization techniques of organizational strategies represented in literature and practical organizational activities:

1. Increase in profitability due to the growth of production volume.

2. Decrease in expenses due to costs reduction.

3. Increase in profitability and decrease in expenses due to efficient use of resources: growth of production volume and costs optimization.

4. Prevention of violation of standards, prevention of deviations, loss.

5. Compliance with set standards and regulations, plan fulfillment.

The first three methods are connected with the change strategy, the 4 th and the 5th methods are lined to the maintenance strategy. 
We carried out a qualitative and quantitative analysis of the criteria content (content analysis) at the second stage. Appropriateness of the application of content-analysis is proved by the fact that the criteria enumerated by participants at random possess traces of various subjective psychological factors, which, in its turn, offers an opportunity to reveal and measure these factors by registering corresponding indicators in the text (Bogomolova \& Stefanenko, 1992). A qualitative unit of the content analysis, i.e. a category, was defined as a key concept that allowed dividing the criteria into groups. The criteria for assessing professional activities of managers obtained during the research were sorted according to two principles: a strategic targeted orientation of a company (target-oriented indicators) and a method of realization of an organizational strategy (activity-related indicators). Table 1 contains examples of content of the criteria for the given groups.

Table 1

\section{Cluster distribution of a professional activities criteria}

\begin{tabular}{|l|l|}
\hline Change strategy: an orientation to changes (to development) \\
\hline $\begin{array}{l}\text { increase in profitabili- } \\
\text { ty due to the growth of } \\
\text { production volume }\end{array}$ & $\begin{array}{l}\text { a number of a newly attracted customers; increase in in- } \\
\text { come; project completion; increase in product output; } \\
\text { growth of sales as compared to the estimated sales }\end{array}$ \\
\hline $\begin{array}{l}\text { decrease in expenses due } \\
\text { to costs reduction }\end{array}$ & $\begin{array}{l}\text { decrease in expenses; energy saving; } \\
\text { absence of: incidents (breakdowns), claims, reclamations, } \\
\text { professional errors }\end{array}$ \\
\hline $\begin{array}{l}\text { increase in profitability } \\
\text { and decrease in expens- } \\
\text { es due to efficient use } \\
\text { of resources: growth of } \\
\text { production volume and } \\
\text { costs optimization }\end{array}$ & $\begin{array}{l}\text { net profit; marginal profit; return on equity (ROE); return } \\
\text { multanent (ROI); attraction of new resources with si- } \\
\text { investment project fulfillment; completion of a plan related } \\
\text { to the cost of production; increase in energy efficiency }\end{array}$ \\
\hline $\begin{array}{l}\text { Maintenance strategy: orientation to functioning in a pre-determined mode in ac- } \\
\text { cordance with set standards and regulations }\end{array}$ \\
\hline $\begin{array}{l}\text { compliance with set } \\
\text { standards and regulati- } \\
\text { ons, plan completion }\end{array}$ & $\begin{array}{l}\text { plan completion; carrying out tasks given by managers; } \\
\text { new ideas and offers; } \\
\text { development of existing directions; } \\
\text { progress control; performance of job duties; appraisal of an } \\
\text { inner customer; program execution }\end{array}$ \\
\hline $\begin{array}{l}\text { prevention of violations } \\
\text { of standards, prevention } \\
\text { of deviations and losses }\end{array}$ & $\begin{array}{l}\text { correction of errors; absence of standstills; provision of } \\
\text { continuous work }\end{array}$ \\
\hline
\end{tabular}


Table 2 contains the results of quantitative distribution of the criteria obtained when filling in a simulated matrix.

Table 2

\section{Quantitative distribution of main criteria clusters}

\begin{tabular}{|l|c|}
\hline \multicolumn{1}{|c|}{ Name of criteria clusters } & $\begin{array}{c}\text { Number of cri- } \\
\text { teria per cluster }\end{array}$ \\
\hline \multicolumn{1}{|c|}{ Change strategy } & 96, of which \\
\hline increase in profitability due to the growth of production volume & 60 \\
\hline decrease in expenses due to costs reduction & 19 \\
\hline $\begin{array}{l}\text { increase in profitability and decrease in expenses due to efficient } \\
\text { use of resources: growth of production volume and costs optimi- } \\
\text { zation }\end{array}$ & 17 \\
\hline \multicolumn{1}{|c|}{ Maintenance strategy } & 108 , of which \\
\hline $\begin{array}{l}\text { compliance with set standards and regulations, plan completion } \\
\text { losention of violations of standards, prevention of deviations and }\end{array}$ & 94 \\
\hline
\end{tabular}

The list of criteria for effectiveness of professional activities drawn up during the analysis of the research results provided the basis for verifying the hypothesis about a degree of representation of indicators directly related to activities in a subjective criterion scale of respondents. Three levels of indicators (according to a level of generalization) are the most frequently singled out in references concerning appraisal of effectiveness of activities (Ismagilova, Mirolyubova, 2009): economic (characterizing an amount of goods, products, money), organizational (characterizing a complex of actions related to creation of labor conditions and organization of production processes in conformity with objectives of a company), activity-related (characterizing quality and quantity of a result as well as efforts to achieve it). If we take the total number of criteria in this cluster as one, the distribution of criteria can be represented in the following manner (Table 3):

Table 3

Distribution of criteria on the basis of "effectiveness level"

\begin{tabular}{|c|c|c|c|}
\hline \multirow{2}{*}{ Name of criteria cluster } & \multicolumn{3}{|c|}{ Ratio of criteria on the basis of "effectiveness level" } \\
\cline { 2 - 4 } & Economic & Organizational & Activity-related \\
\hline Change strategy - 1 & 0.35 & 0.4 & 0.25 \\
\hline Maintenance strategy - 1 & 0.6 & 0.3 & 0.1 \\
\hline
\end{tabular}




\section{Preliminary Conclusions}

On the basis of the data obtained, we can confidently single out 5 main groups of criteria that are represented in individual consciousness of managers-respondents and employed to assess effectiveness of managers' professional activities. The criteria that point to increase in the result of such activity (cluster "increase in profitability due to the growth of production volume"; total number of references is 60) or the support of activities (cluster "compliance with set standards and regulations, plan completion; total number of references is 94) prevail among said criteria. In should be noted that no indicator bears a relation to what is understood under the notion "effectiveness" in terms of its content.

The obtained results confirm the hypothesis stating that criteria of increasing profitability and criteria of decreasing expenses in most cases do not agree with each other and exist as independent groups in a subjective system of criterion-oriented support of respondents' activities. Only few criteria suggested by the respondents take into account the ratio between an obtained result and efforts. Thus, we can state that the respondents substitute criteria of efficiency themselves by criteria that describe a result or a process when assessing effectiveness of activities. It goes without saying that such substitutions can not but affect quality of professional activities of managers, because the professional activities cease to be a subject of analysis and of improvement for an individual. From our point of view, it is directly connected with the problem of enhancing professional competence of managers of modern companies.

Though the results of the research did not exactly confirm the hypothesis about the predominance of the criteria for assessing activities targeted to supporting the existing company strategy over the criteria for assessing activities targeted to the process of organizational changes. This is an implicit evidence of a positive shift towards innovative orientation of the organizational development as compared to the conclusion obtained by the authors in the previous research (Ismagilova, Mirolyubova, 2009).

The results of our research further demonstrate that managers tend to rely more on of economic and organizational indicators, when assessing professional activities. The fact that activity-related indicators are used by respondents more often when there is orientation to the support strategy than to the strategy of changes. If we take into account that the former mainly describe a process and the latter relate to a result, then the 
question of how clear the notion of potential results of managerial activities in managers is can be a subject of the further discussion.

\section{Prospects of Further Research}

Undoubtedly, the obtained results can outline the area for future studies only as a rough approximation. It is worth mentioning, though, that research in specific features of professional experience of managers having various records of service, dynamics of experience formation on the basis of a study of subjective preferences of criteria, allows focusing attention on activities both as a source of experience formation and its consequence. In the age of economy of knowledge, the issues of interpretation of organizational knowledge in an employee's professional activities, as well as those aspects of personal knowledge that determine its quality and influence its efficiency become extremely important. From our point of view, this research should be integrated, interdisciplinary and practically-oriented due to social and economic significance of tasks that they are intended to solve.

\section{References}

Bogomolova, N.N., \& Stefanenko, T.G. (1992). Kontent-analiz: spetspraktikum po social'noj psihologii [Content-analysis: practical work in social psychology]. Moscow: Moscow State University.

Fletcher, C. (2008). Performance appraisal: assessing and development performance. In N. Chmiel (Ed.), An introduction to work and organizational psychology: a Europe perspective (pp. 76-96). Oxford, UK: Blackwell Publishing Ltd.

Keith, A.M., \& Madhukar, A. (2006). The Importance of Work Experience to Accountants' Professional Development. The Journal of American Academy of Business, Cambridge, 9 (2).

Ismagilova, F.S., \& Mirolyubova, G.S. (2009). Psihologicheskie aspecty' vy'bora innovatsionnoj strategii na proizvodstvenny'h predpriyatiyah Ural'skogo regiona [Psychological Aspects of Selecting an Innovative Strategy at Production Companies of the Ural Region.]. Psihologicheskij vestnik Ural'skogo gosudarstvennogo universiteta [Psychological Bulletin of the Ural State University], 7, 3-20.

Strelkov, Yu.K. (2008). Struktura professional'nogo opy'ta [Structure of a Work experience]. In V.I. Panov \& N.L. Morina (Eds.), D.A. Oshanin i sovremennaja psihologija: K 100-letiju so dnja rozhdenija D.A. Oshanina [D.A. Oshanin and Modern Psychology: To the $100^{\text {th }}$ Anniversary of D.A. Oshanin] (pp. 187-209). Moscow; Obninsk: IGSOTSYN. 